\title{
Effect of Lime and Compost Application on the growth and yield of Common Bean (Phaseolus Vulgaris L.): A Review
}

\author{
Gudeta Dida* and Damtew Etisa \\ Ethiopian institute of Agricultural Research, Ethiopia
}

*Corresponding author: Gudeta Dida Hordofa, National Agricultural Biotechnology

Research center, Ethiopian institute of Agricultural Research, Ethiopia.

Received Date: March 13, 2019

Published Date: March 28, 2019

\begin{abstract}
Common bean (Phaseolus vulgaris) was domesticated $~ 8000$ years ago in the Americas and today is a staple food which has been consumed worldwide for its edible seeds and pods. In Ethiopia, it is one of the most important cash crops and source of protein in many areas. However, the national average yields are by far below the average yield reported in different countries. This low national average yield is due to poor soil fertility management and low nutrient availability associated with acidic soils. Most of the major common bean producing areas in Ethiopia is characterized by high rainfall and acidic soils which resulted in high nutrient fixation and low nutrient availability. Acidic soils are suggested as one of the most important soil factors which limit crop production and it is also phytotoxic which result in nutritional disorders and deficiencies of different soil nutrients for crop production. To cope with these production constraints, using of compost and lime are recommended. Lime is suggested to enhance soil health status through improving soil physic-chemical properties and neutralize the acid produced in the soil. In addition to this, it reduces $\mathrm{Al}+3$ and $\mathrm{Mn}+2$ toxicity and increases both $\mathrm{P}$ uptake in high $\mathrm{P}$ fixing soil and plant rooting system and improves common bean nitrogen fixation. Compost is also suggested as an option for improving soil fertility and increasing yield of common bean for poor farmers. The use of Compost in sustainable agriculture benefits farmers, growers, consumers and the environment in many ways. The proper combination of lime and compost application also has the potential of contributing to an overall increase of common bean yields due to the change in soil physio-chemical properties and enhance soil biological $\mathrm{N}$ fixation. This study sought to review the Effect of lime and compost application on the growth and yield of common bean in Ethiopia.
\end{abstract}

Keywords: Compost; Common bean (Phaseolus vulgaris L.)

\section{Introduction}

Common bean (Phaseolus vulgaris) was domesticated $\sim 8000$ years ago in the Americas and today is a staple food which has been consumed worldwide for its edible seeds and pods Heuze $\mathrm{V}$ et al. 2015. It is widely appreciated in developing countries for their affordability and its long storage life. It is widely distributed throughout the world with total global production of about 25 million MT with a productivity of $792 \mathrm{~kg} / \mathrm{ha}$ FAOSTAT [1] out of which about 6 million MT is produced in Africa FAOSTAT [2]. Latin America and sub-Saharan Africa are the leading producers of common bean. It is also cultivated in many parts of the tropics and sub-tropics as well as throughout the temperate regions with approximate contributions of three-quarters of the global production Katungi et al. [3] due to its high in starch, protein and dietary fiber and is an excellent source of potassium, selenium, molybdenum, thiamine, vitamin B6, and folic acid Maiti RK and Singh VP [4]. The ripe seeds cooked for soups and broth in the world (Brucher et al. [5]. Common bean also has the economic and environmental benefit of associating with nitrogen-fixing bacteria that gives an advantage to fix atmospheric nitrogen and leaving phosphorous (P) for plant growth.

Common bean (Phaseolus vulgaris L.) is one of the most grain legumes cultivated in Ethiopia. It is the source of protein, vitamin, mineral and most important cash crops in many lowlands and mid altitude zones of Ethiopia A. Asfaw M.W. [6]. It is the most important crop for food security and wealth creation. More than 337,000 hectares were dedicated to production of 455,000 tons 
of common beans annually FOASTAT [7] and contributes to the national economy as both a food and an export commodity, in both cases serving as a source of income and employment to a large supply chain K. Tumsa R. [8]. Over $85 \%$ of country's export earning comes from pulses (lentils, Faba bean, chickpea and common bean) Negash [9]. Common bean contributes about $9.5 \%$ of total export value of the country from agriculture sector FAOSTAT [10]. It also highly preferred due to its fast maturing characteristics that enable households to get cash income and source of food Legesse [11].

Common bean is among the top-ranking pulses in terms of area coverage, with an increasing trend for the last few years CSA [12]. It is cultivated in most of the agro-ecological zones of low and mid altitude areas of Ethiopia Wortmann et al. [13] with area of about 0.37 million hectare and total annual production of 0.51 million MT FAOSTAT [2]. The average national yield of common bean in Ethiopia is estimated at $1300 \mathrm{~kg} \mathrm{ha}^{-1}$ on smallholder farms and $1700 \mathrm{~kg} \mathrm{ha}^{-1}$ on commercial farms CSA, 2016 [14] in contrast to a production potential of 3000 to $4000 \mathrm{~kg} \mathrm{ha}^{-1}$ in research fields IFPRI, M.W. Blair $[15,16]$. In terms of geographical distribution of production, Oromia took the lion's share $(51 \%)$ of common bean production in the country, followed by SNNPR (27\%), Amhara (20\%) and, Benishangul-Gumuz (1\%) and the other regions contributing 1\% of the country's total production CSA, [12]. However, the national average yields (1.59 $\mathrm{t} \mathrm{ha}^{-1}$ ) CSA, [12] is by far below the average yield reported at research sites (2.5 to $3.0 \mathrm{t} \mathrm{ha}^{-1}$ ) Frehiwot [17].

The low national average yield may be attributed to a combination of several production constraints. Among others, poor soil fertility management and low nutrient availability associated with low $\mathrm{pH}$ of the soils are among the tops. More importantly, most of the major common bean producing areas in Ethiopia is characterized by high rainfall and acidic soils which are associated with high nutrient fixation and low nutrient availability (Negash [9]. This Acid soil is phytotoxic to many crops due to nutritional disorders, deficiencies and unavailability of essential nutrients. Soil acidity is one of the most important soil factors which affect plant growth and ultimately limit crop production Fageria [18]. In acidic soils, the high content of $\mathrm{Al}$ and Fe oxides and hydroxides are the main factors accounting for the strong macronutrient such as P fixation in the highlands of Ethiopia and consequently, limits crop production Asmare, [19]. Nutrient deficiency has also been shown to be an important fertility problem limiting legume production and reduces growth, nodulation, and $\mathrm{N}_{2}$ fixation. Acidic soils are toxic to plant roots and inhibit microorganism's activity, such as Rhizobium spp, which influences nutrient uptake and crop growth. To overcome these production constraints, the application of compost and lime are recommended to cope with problem of soil acidity by raising acidic soil $\mathrm{PH}$ and to increase soil fertility.

The use of lime in legume production is believed to enhance soil health status through improving soil $\mathrm{pH}$, base saturation, $\mathrm{Ca}$, $\mathrm{Mg}$ and enhance $\mathrm{P}$ availability. It is found that as the lime and $\mathrm{P}$ application to acid soils increased plant available $\mathrm{Fe}, \mathrm{Mn}, \mathrm{Zn}$ and $\mathrm{Cu}$, but B contents of soil decreased, whereas $\mathrm{pH}, \mathrm{Ca}, \mathrm{Mg}$ and available $\mathrm{P}$ increased which in turn improve crop performance Ponette et al.
[20]. The extension of this approach in semiarid region of Ethiopia appears to be promising. It reduces $\mathrm{Fe}, \mathrm{Al}$ and $\mathrm{Mn}$ toxicity level and increases both P uptake in high P fixing soil, chemical and biological systems of the soils and plant rooting system Ndakidem [21]. Liming is the most common management practice used to neutralize the acid soil and the problems associated with soil acidification and it is best method to maintain a suitable $\mathrm{pH}$ for the growth of a variety of crops, improved nitrogen fixation and availability of essential nutrients (Ca, P, and Mo) Slattery \& Coventry [22]. Liming also used to decrease the solubility of toxic elements like that of $\mathrm{Al}$ and $\mathrm{Mn}$ in soil Haynes \& Ludeke [23]. Liming has been shown to provide optimum conditions for a suite of biological activities and have the potential to increase soil organic matter levels to these and improve soil quality when added to these soils in significant quantities.

The use of organic-based fertilizers in sustainable agriculture benefits farmers, growers, consumers and the environment in many ways. Currently it is the option for improving soil fertility conditions for poor farmers. The use of compost increases the soil organic carbon and soil $\mathrm{pH}$, improves the soil structure, decreases bulk density, decrease soil acidity, nurture the soil with organic matter that reduces dependency on chemical inputs, improve the structure of the soil including the circulation of air, enhance soil fertility, provides macro- and micronutrients, and enhances microbial activity. It used as a growth factor for crops and source of production of new Organic Matter when added to soil Gallardo $\&$ Nogales [24]. Compost can in short term, increase in aggregate stability to water, proportionally to the organic carbon content of soil.

Proper combined application of liming and composting the acid soils has the potential of contributing to an overall increase of common bean yields cultivated in such soils because of reducing exchangeable acidity and increasing $\mathrm{pH}$ and soil fertility Onwonga et al. [25]. Therefore, the practice of well-planned and execution of liming and composting is fundamental to improve soil fertility and for increasing common bean yields on acid soils. This in turn helps to reduce crop production risks associated with soil acidity, as both of them promote nutrients use efficiency. However, Information on the low soil fertility and extent of soil acidity problems on common bean production and their amendments through lime and compost to reclaim this soil in different integration form is not well documented. Thus, this study sought to review the Effect of lime and compost application on the growth and yield of common bean.

\section{Description of the crop}

The common bean is a highly variable species that has a long history of cultivation. All wild members of the species have a climbing habit, but many cultivars are classified as "bush beans" or "pole beans; with many lateral and adventitious roots; stem up to $3 \mathrm{~m}$ long, angular or nearly cylindrical. Leaves are 3-foliolate and alternately arranged; inflorescence an axillary or terminal false raceme up to $15-35 \mathrm{~cm}$ long, with flowers arranged along the rachis in pairs or solitary. Flowers are bisexual Broughton et al. [26]. Common beans are an annual, mostly self-pollinated leguminous 
plant cultivated for food in many parts of the world. P. vulgaris originated in Mesoamerica and diverged, about 110,000-165,000 years ago, into Mesoamerican and Andean gene pools that are now partially reproductively isolated Mamidi et al. [27]. P. vulgaris was then domesticated independently in Mesoamerica and the Andes approximately 7,000 years ago, and cultivation has over the centuries spread from these two domestication centers to large areas in the tropics and subtropics.

Presently, common bean is the most important crop legume for direct human consumption with over 45 million tons of beans produced in 2013 FAOSTAT [1], primarily in Latin America, SubSaharan Africa (SSA), and Asia. The consumption of P. vulgaris is mainly as dry grain (dry beans) or as a green pod (green beans). Less frequently, the immature seed or leaves are eaten. Beans provide dietary protein, carbohydrates, fiber and are a good source of vitamins and minerals such as potassium and phosphorous Broughton et al. [26].

\section{Importance of Common Bean Production in Ethiopia}

Common bean plays a role of paramount importance in human nutrition and market economies throughout rural and urban areas of eastern Africa Wortmann et al. [28]. Bean provides the third most important source of calories after maize and cassava Pachio [29]. Common bean is among the five most important food legumes of Ethiopia. It is mainly grown at intermediate (1400-1800m) altitude CSA, 2000 [30]. One of the main reasons for the expansion of the area used for bean production has been the prevalence of drought and or low and erratic rainfall particularly in the intermediate altitudes because most of the beans mature within three months and are able to give reasonable yields when rains are poor, escaping end of-season drought. Also, crop production is expanding in low altitude areas, where other traditional pulses perform poorly due to disease and pests. In these areas, bean performs very well and is a cheap source of protein CIAT [31].

Common bean is grown in most part of Ethiopia, production is mainly concentrated in east (Hararghe highlands), the south and south west (Sidamo), in the Rift valley system and other arid and semiarid zones. Productivity of the crop is often constrained by problems of soil acidity and low soil fertility. Particularly, soil acidity is major constraints, due it causes low $\mathrm{P}$ availability and $\mathrm{Al}$ and Mn toxicity is of localized importance CIAT [31].

\section{Soil Acidity in Ethiopia}

The total area of Ethiopia is 111.8 million hectares out of these only 79 million of hectare is suitable for agriculture. Out of these about $40.9 \%$ of area is covered by strongly to weak acid soils. From these $27.7 \%$ moderately to weak acids with pH 5.8-6.7 and $13.2 \%$ covered by strong to moderate acidic soils with $\mathrm{pH}$ less than 5.5 (Schlede 1989). The strongly acid soils are found in ecologies which receive or have historically received high incidence of rainfall and have warm temperatures much of the year. They are often found in Oxisols, Nitosols and Ferralsols. Thus, the most strongly acidic soils are found in western and south western parts of Ethiopia, the central highlands, the high rainfall areas of north western part of the country (Paulos, 2001). Nevertheless, moderately acidic soils (pH 5.5-6.5) are distributed through much of the rest of the country Taye [32]. In Western and Eastern Wollege zones, the large proportions exchangeable acidity was due to exchangeable Al while at west Shoa Zone it was due to exchangeable $\mathrm{H}^{+}$.

\section{Impact of soil acidity to common bean root development and soil microorganisms}

Acidity refers to concentration of hydrogen cations in a solution (FAO, 2006). The pH values range from 0 to 14 in which below 7 indicates an acid solution, above 7 alkaline and 7 neutral solutions Singh \& Breman [33]. The natural pH of a soil depends on the nature of the material from which it was developed (TSO, 2010). In most soils' pH ranges from 2.0 to 11 (Batjes, 1995) and is used for classifications of soils (Landon, Soil Survey Staff, Kanyanjua et al. [34]. Table 1 shows classification of soils according to the level of $\mathrm{pH}$.

Table 1: Classification of soil acidity according to the level of $\mathrm{pH}$.

\begin{tabular}{|c|c|}
\hline Soil acidity class & PH range \\
\hline Extremely acidic & $<4.5$ \\
\hline Strongly acidic & $4.4-5.0$ \\
\hline Moderately acidic & $5.0-6.0$ \\
\hline Slightly acidic & $6.0-6.5$ \\
\hline Near neutral & $6.5-7.0$ \\
\hline
\end{tabular}

In acid soils, common bean is affected directly and indirectly. These effects include injury on plant roots therefore reducing water and nutrient uptake, reduced availability of essential plant nutrients, toxicity of $\mathrm{Al}$ and Manganese (Mn) and survival of microorganisms in the soil Crawford et al. [33]. Soil microbiological properties can serve as soil quality indicators because soil microorganisms are the second most important (after plants) biological agents in the agricultural ecosystem Fageria [18]. Soil microorganisms provide the primary driving force for many chemical and biochemical processes and thus affect nutrient cycling, soil fertility, and carbon cycling He et al. [35]. Plant roots and rhizosphere are colonized by many plant- beneficial microorganisms such as symbiotic and nonsymbiotic nitrogen (N_2) fixing bacteria; plant growth promoting rhizobacteria, saprophytic microorganisms, bio-control agents, and mycorrhizae and free-living fungi. Soil acidity affects the activities of these beneficial microorganisms Brady \& Weil [36].

Acidity of soil affects plants in many ways. For instance, Al prevents plant root elongation due to its direct effect on metabolism or indirectly by rendering the phosphate in the soil unavailable by binding it to form aluminum phosphates thereby leading to overall low crop yields. Plant species and varieties differ, in their sensitivity to the conditions in acid soils. Common bean lies in the medium tolerance range and would do well in the 5.5-6.0 $\mathrm{pH}$ range Mora et al. [24]. Acidity produces complex interactions of plant growth-limiting factors involving physical, chemical, and biological properties of soil. Among biological properties, activities 
of beneficial microorganisms are adversely affected by soil acidity which has profound effects on the decomposition of organic matter, nutrient mineralization and immobilization, uptake and utilization by plants and consequently on crop yields Huber [37]. Soil microorganisms especially bacteria and fungi have been shown to be sensitive to organic amendments and lime application Magdoff [38]. Organic such as compost and lime amendments are known to increase the abundance of various components of the soil food web, including the soil fungal and bacterial communities Forge et al. [39]. Changes in soil microbial communities across space are often strongly correlated with differences in soil chemistry Nilsson et al. [40]. It has been shown that the composition and in some cases diversity of soil bacterial communities are often strongly correlated with soil pH Lauber et al. [41]. This pattern holds both for overall bacterial community composition Lauber et al. [41] and for the composition of individual bacterial groups Jenkins et al. [42].

Many researchers have proved that many microorganisms in soil produce organic acids like carbonic acids, acetic acids, citric acids, etc. These acids create favorable environment for the enhancement of P solubility and uptake by plants Sharif et al. [43]. Kucey et al. [44] have shown from liquid medium studies that the microbial solubilization of soil phosphate has often been due to excretion of organic acids. The availability of Phosphorus for plant uptake can therefore be increased by treatment with mineral acids, organic acids, and a mixture of organic materials, biological treatment, etc. Incorporating compost and lime has been shown to enhance the solubility Sharif et al. [43].

\section{Effects of liming on soil pH}

As soils become increasingly acidic (decreasing $\mathrm{pH}$ ), important nutrients like phosphorus become less available to plants. Increasing the $\mathrm{pH}$ of acidic soils via Liming improves plant-availability of some nutrients while reducing the solubility of elements such as $\mathrm{Al}$ and Mn (Hue and Licudine, 1999). Source: Ristow PL [45]. Application of lime tends to raise the soil pH by displacement of $\mathrm{H}+, \mathrm{Al} 3+$, Iron, Manganese and cupper ions from soil adsorption site Onwonga et al. [25].The main reason why manure raises soil $\mathrm{pH}$ is due to the presence of calcium and magnesium elements in it and its buffer capacity because of forming complexes with $\mathrm{Al}$ and $\mathrm{Fe}$ in acid soils. Bickelhaupt (1989) reports that the application of composted limetreated manure to a slightly acidic soil increased soil $\mathrm{pH}$ to between 6.7 and $7.3 \mathrm{pH}$. An increase in water dispersible clay following liming has also been observed by other workers when acidic tropical soils $(<\mathrm{pH} 4.0)$ are limed into the range of 5.0 to 6.0 (Castro and Logan, 1991) (Figure 1).

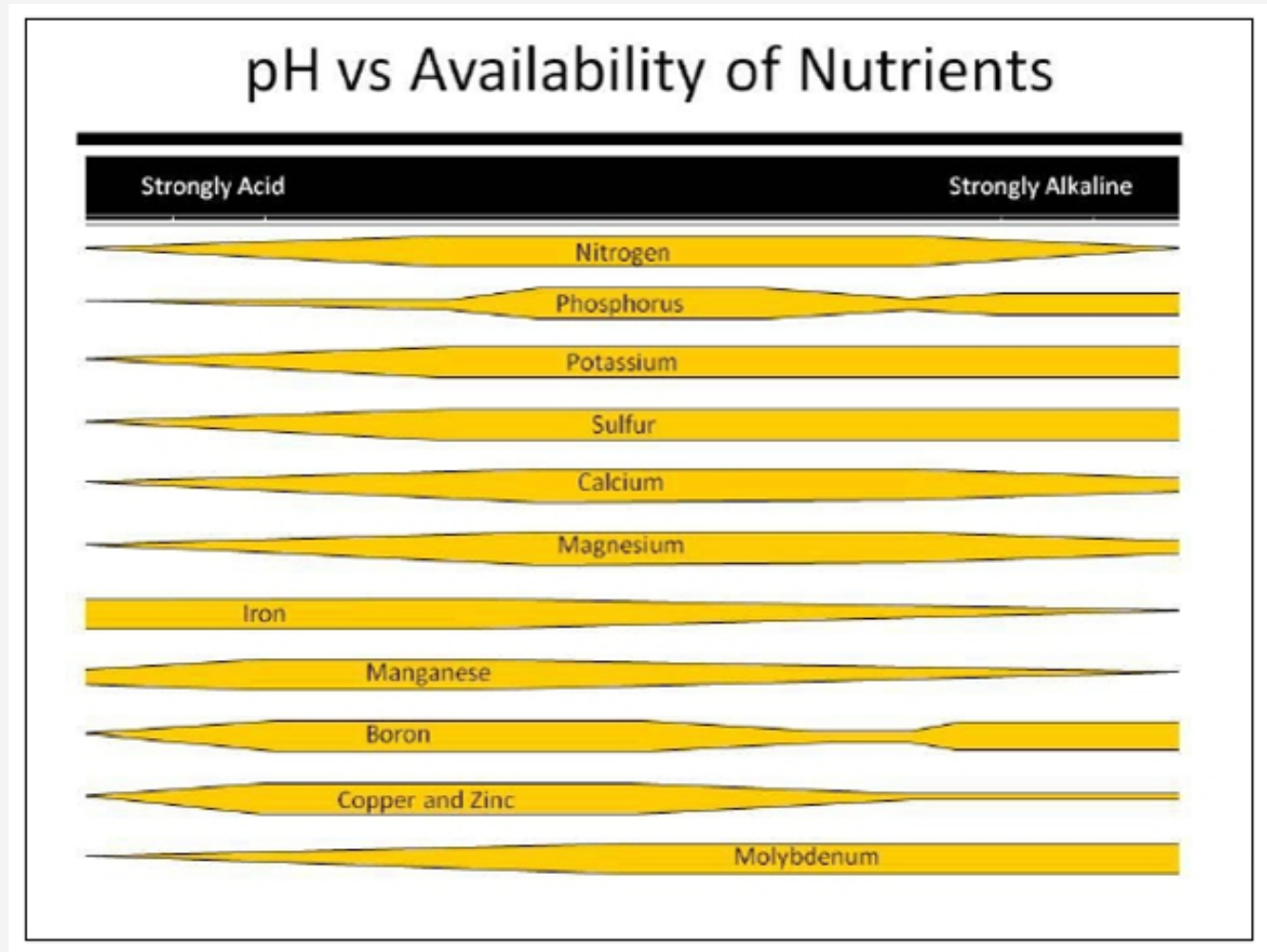

Figure 1: Map of the study area (modified form Google map).

\section{Effects of Compost on soil pH}

The effect of compost on soil pH is depend both on the initial $\mathrm{pH}$ of the compost and the soil pH (Crecchio et al., 2001).There is evidence that compost can increase the $\mathrm{pH}$ of acid soils and improve soil fertility by supplying nutrients for crop production (Wong et al., 1998).The main reason why compost raises soil pH is due to the presence of calcium and magnesium elements in it and its buffer capacity because of forming complexes with $\mathrm{Al}$ and $\mathrm{Fe}$ in acid soils (Tang et al., 2007). Patil et al (2003) also carried out a study to know the effect of compost on soil $\mathrm{pH}$ and showed that there was decrease in $\mathrm{pH}$ from 7.99 to 7.65 and each increment of compost reduced the soil pH significantly due to organic acid production during its decomposition. Study conducted in Kaka mega to assess the effects of liming and compost on common bean 
yield revealed that a combination of lime with compost increased soil $\mathrm{pH}$ levels from ranges of 4.63 to 5.8 which were optimum ranges for common bean yields and this resulted in an increase in maize yields (Mbakaya et al., 2010).

\section{Effects of Compost and Lime Application on Common Bean Yields}

\section{Effects of compost application on common bean yields}

'Organic fertilizers are derived from plants and animal parts and have a wide role in agricultural production system. Application of compost has significant impact on the chemical, physical and biological properties of the soil. Most of these effects are due to an increase in soil Organic matter Souza RF [46]. Manure is an excellent source of major plant nutrients such as $\mathrm{N}, \mathrm{P}$ and $\mathrm{K}$ and provides many of the secondary nutrients that plants require. When added to the soil they increase its organic matter content and improve soil physical properties. Furthermore, improvement in soil organic matter (SOM) leads to slow release of crop nutrients (Nitrogen $(\mathrm{N})$, Phosphorus (P) and Potassium (K)); improve buffering capacity of the soil and cation exchange capacity (Gachene \& Kimaru, 2003). The actual nutrient value of compost from a particular operation will differ considerably due to the type of animal, its food ration, manure collection, storage, application procedures and climate (Risse et al., 2006). Compost increase infiltration (Risse et al., 2006), water holding capacity (Rasoulzadeh \&Yaghoubi, 2010; Liang et al., 2011) and reduced compaction and erosion (Salahin et al., 2011).

According to Kihanda et al. (2007) compost application is one of the most effective ways of improving fertility in tropical soils. Approximately $80 \%$ of households in Central highland of Kenya use compost as a fertilizer (Makokha et al. 2001). In Kenya Gido et al (2013) studied the organic soil management practices through a household survey with 650 smallholder maize farmers in Bungoma County, Western Kenya. To improve soil fertility, $70.7 \%$ of the respondents applied farm yard manure, $62.7 \%$ incorporated crop residues into the soil, $60 \%$ applied animal manure, $55.3 \%$ planted leguminous crops and $42 \%$ used green manure on their farms.

This compost has been used as fertilizer on smallholder farmers in order to increase crop production and have been shown to be an alternative for improvement of crop yields in central highlands of Kenya (Mugwe et al., 2007). Javaid and Mahmood (2010) in Pakistan, found significant effect of farm yard manure on soybean pod number. Elsewhere, the application of poultry manures also increased dry matter per hectare and grain yield (Maheshbabu et al., 2008; Tagoe et al., 2008; Chiezey \& Odunze, 2009).

\section{Effects lime application on common bean yields}

Lime are materials containing carbonates, oxides or hydroxides required to apply in acid soils to raise soil $\mathrm{pH}$ and in addition neutralize toxic elements in the soil. Soil $\mathrm{pH}$ is used to determine whether to lime a soil (TSO, 2010). Liming materials include, $\mathrm{Ca}, \mathrm{Mg}$ $\left(\mathrm{CaCO}_{3}\right) 2, \mathrm{Ca}(\mathrm{OH})_{2}, \mathrm{CaO}$ and others, which vary according to their neutralizing value and degree of fineness (TSO, 2010). Application of lime tends to raise the soil $\mathrm{pH}$ by displacement of $\mathrm{H}^{+}, \mathrm{Fe}^{2+}, \mathrm{Al}^{3+}$ and
$\mathrm{Mn}^{4+}$ ions from soil adsorption site, and subsequent neutralization of $\mathrm{H}^{+}$and precipitation of $\mathrm{Fe}, \mathrm{Al}$, and $\mathrm{Mn}$ as hydroxides and $\mathrm{Cu}$ ions from soil adsorption site resulting in increase in soil pH Onwonga RN [25]. Other than increasing soil pH, lime also supplies significant amounts of $\mathrm{Ca}$ and $\mathrm{Mg}$, depending on the type of soil. Indirect effects of lime include increased availability of P, Mo, B and more favorable conditions for microbially mediated reactions such as N2 fixation and nitrification, and in some cases improved soil structure Crawford TW Jr [33].

In Nigeria application of lime significantly increased root and shoot yields (Anetor \& Akinrinde, 2006) and grain yields of soybean in Brazil (Kassel et al., 2000; Caires et al., 2006). Similarly, in Croatia Andric et al (2012) reported increased soybean yield by $44 \%$ because of lime application. Moreover, Nekesa et al (2011) in Western Kenya also found positive response of common bean grain yield to lime application either alone or combined with P fertilizer.

\section{Combined Effects of Lime and Compost on Growth of Common Bean}

The importance of applying organic or inorganic form has been proven in various researches. However, use of compost alone has a slow but positive effect in releasing nutrients since they require microbial activity to decompose it. Inorganic fertilizers are of rapid nutrient availability but expensive and are easily leached from the soil. However, application of combined organic and inorganic fertilizers is a viable solution to restore, maintain soil fertility, and increase crop yields (Danga et al., 2010; Sharief et al., 2010). Most of the reports (Asgelil D, Getachew A et al. [47-48] revealed significant improvements on the yield of faba bean due to chemical fertilizers and manure applications. Manisha et al. [49] revealed that the integrated application of organic wastes and chemical fertilizer in conjunction with lime significantly improved the yield and quality of peanut.

The effects of compost along with lime on the yields of pea were investigated by Chiezey \& Odunze, (2009) and found that germination was in the range $85-95 \%$ and was not affected by any treatment. They also concluded that maturity was slightly delayed by increasing rates of added compost and slightly advanced by increasing rates of added lime. In another study, highest yield of peas was obtained with 1.5-ton compost and 3.0 t dolomitic lime stone ha-1 (Mugwe et al., 2007).

Maheshbabu et al (2008) in India found that combination of FYM and mineral fertilizer had a significant effect not only on soybean grain yield but also on its growth parameters. Anetor and Akinrinde (2006) in Nigeria reported that combined lime and organic fertilizer had a significant effect on the number of pods, pod heights, branches, better grain yields and seed number of soybeans. Similarly, in Ethiopia the combined Application of 8 t FYM ha ${ }^{-1}+30 \mathrm{~kg} \mathrm{Pha}^{-1}+3.6 \mathrm{t} \mathrm{lime} \mathrm{ha}^{-1}$ on faba bean increased number of pod per plant from 3.4 to 9.2, straw yield from 1037 to $2904 \mathrm{kgha}^{-1}$ and biological yield from 1910 to $4431 \mathrm{~kg} \mathrm{ha}^{-1}$ Fikedu E et al. [50]. Similarly, in India (maheshbabu et al., 2008) reported that combined application of organic and inorganic fertilizer 
increases soybean yield by $12.9 \%, 19 \%$ in Indonesia relative to sole application of inorganic fertilizer (Yamika \& Ikawati, 2012), and $50 \%$ against sole application of organic fertilizer (compost) (Zerihun et al., 2013).

\section{Effects of compost and lime on soil chemical properties}

Soil chemical properties include $\mathrm{pH}$, exchangeable acidity $(\mathrm{H}$, $\mathrm{Al}$ ) and exchangeable bases ( $\mathrm{Ca}, \mathrm{Mg}, \mathrm{K}$ and $\mathrm{Na}$ ). These properties influence availability of nutrients to crop, and therefore have potential to reduce or increase crop yields. Application of soil amendments leads to improvement in soil chemical properties creating favorable conditions for crop nutrition, development and yield. Ndayegamiye and Cote (1988) reported significant increase of $7.6 \%$ and $15.2 \%$ in CEC at the rates of 4.0 and 6.0 -ton ha ${ }^{-1}$ of compost respectively. Similar reports on an Alfisol in Nigeria Ayuba et al (2005) found that available P increased significantly while total $\mathrm{P}$ was as high as $7.21 \mathrm{ppm}$ following application of 15 -ton $\mathrm{ha}^{-1}$ of compost.

In a comparative study of organic manures and NPK fertilizer in acid soil, Adeniyan et al (2011) found that 5-ton ha-1 of cattle manure significantly increased soil available $\mathrm{P}, \mathrm{pH}$, organic $\mathrm{C}$ and cation exchange capacity. Kheyrodin and Antoun (2012) found that manure increased significantly soil $\mathrm{P}, \mathrm{Ca}$ and $\mathrm{Mg}$ contents in the 15 - $30 \mathrm{~cm}$ depth. Application of 2-ton ha ${ }^{-1}$ of lime decreased exchangeable $\mathrm{Al}$, and increased $\mathrm{pH}$, available $\mathrm{Ca}$ and $\mathrm{Mg}$ in Cameroon (The et al., 2001. As reported by Anetor and Akinrinde (2006) Lime and $\mathrm{P}$ fertilizers significantly improve soil $\mathrm{pH}$ and availability of phosphorus. Repsiene and Skuodiene (2010) found that lime and compost when applied sole or combined had a significant effect in reducing $\mathrm{Al}$, increasing $\mathrm{Ca}, \mathrm{pH}$, and Mg. Ademba et al (2010) reported significant increase in soil total $\mathrm{P}, \mathrm{K}, \mathrm{Ca}$ and $\mathrm{Mg}$ with sole application of 10 ton ha-1 of manure, $60 \mathrm{~kg}$ P205 ha-1 and $250 \mathrm{~kg} \mathrm{ha}^{-1}$ of lime. In addition, the same study revealed that lime and compost combined with DAP increased available P. In Nigeria, Ewulo (2005) found that application of 6-ton ha-1 of compost increased total soil $\mathrm{P}, \mathrm{K}, \mathrm{Ca}, \mathrm{Mg}$ and cations exchange capacity (CEC), and decreased exchangeable acidity.

Improved physicochemical properties of acid soils have been reported through combination of manure with $\mathrm{N}, \mathrm{P}$ fertilizers and lime Onwonga et al. [25]. The improvement was attributed to the integrated effect of the amendments by improving soil $\mathrm{pH}$, microbial activity, nutrient release from organic matter decomposition and improved soil structure as well. In addition, Kisinyo et al (2012) reported significant positive effects on soil $\mathrm{pH}$ and available $\mathrm{P}$ in acid soil of Western Kenya, with application of lime and P fertilizer in sole or in combination.

\section{Effects of liming on soil cation exchange capacity (CEC)}

Addition of lime usually increases the contribution of organic matter to CEC Curtin \& Syers [51]. Changes in the relative proportions of organic and mineral sites may have some effect on the distribution of cations between the exchange and solution phases of soil Suarez \& Simunek [52]. Since, Plants derive their nutrients including the cations from the soil solution; the concentrations of $\mathrm{Ca}, \mathrm{Mg}$, and $\mathrm{K}$ in the soil solution are determined by cation exchange equilibrium Curtin \& Smillie [51]. Increasing CEC without Mg addition reduces Mg saturation and such lime induced $\mathrm{Mg}$ deficiencies can be quite striking. Exchangeable sodium ( $\mathrm{Na}$ ) alters soil physical and chemical properties mainly by inducing swelling and dispersion of clay and organic particles resulting in restricting water permeability and air movement and crust formation and nutritional disorders (decrease solubility and availability of calcium (Ca) and magnesium (Mg) ions) Suarez and Simunek [52].

\section{Effects of Compost and Lime Application on Nitrogen Fixation of Common Bean}

\section{Effects of lime on Nitrogen fixation of common bean}

Optimal utilization of biological $\mathrm{N}$ fixation (BNF) will be very helpful in increasing production and $\mathrm{N}$ fertilizer use efficiency Rhizobia and their host plants require organic compounds as a source of food and optimal growth environment (Both \& Benites, 2005). Acidity tend to reduce microbial mediate processed that results in poor organic matter decomposition, mineralization of nitrogen and consequently low $\mathrm{N}$ availability. Soil acidity amendments may improve soil for mineralization take place, $p$ availability, increase in soil $\mathrm{pH}$, and increase $\mathrm{N}$ availability in the soil, its uptake, provides a more favorable environment for soil microbiological activity and finally positive influence on increasing crop yield. The application of lime increases nodule number and dry weight, dry matter production and grain yields of soybeans (Ganeshamurthy \& Sammi, 2002). Sudaryono et al (2002) reported $27 \%$ and $97 \%$ improvement in the final production of Tanggamus and Slamet verities respectively in acid soil by using $1 \mathrm{t} /$ ha dolomitic lime and $5 t$ / ha manure. The addition of dolomitic lime equivalent to $1 / 2 \mathrm{x}$ Al-dd (equivalent to $518 \mathrm{~kg} \mathrm{CaO} / \mathrm{ha}$ ) combined with $75 \mathrm{~kg}$ urea $+100 \mathrm{~kg} \mathrm{SP} 36+100 \mathrm{~kg} \mathrm{KCl} /$ ha was able to increase soybean yields to be 1.5 ton / ha (Taufiq et al. 2004).

Inputs in the form of lime in the soil of common bean area increase the number of root nodules. It can be due to of the ability of the two materials in improving the growth environment such as soil $\mathrm{pH}$ and availability of nutrients required by plants and Rhizobium (Brockwell et al., 1991). Studies by Lucrecia et al. [53] and Bekere et al. [54] demonstrated that supply of calcium ion through lime significantly increased nodule weight, nodule number, nodule volume, dry weight and plant productivity in Pirulgaris and the experiment done by Hartley et al. [55], lime supply increased nodulation and yield of Serradella (Ornithopus compressus). The beneficial effects of liming on nodulation and plant growth most likely resulted from the enhanced conditions for seedling growth and nodulation.

Bekere et al. [54] also reported that lime and inoculation at the same time produce the highest nodule number and nodule volume of soybean in Southwestern Ethiopia. The increase in number of nodules production in plants under optimum Rhizobium inoculated and liming combination could be since liming improved supply of 
calcium to plants through enhancing symbiotic association with Rhizobium.

\section{Effects of compost on nitrogen fixation of common bean}

Schmitt etal. (2001) found that application of compostincreased significantly N uptake by soybean. Son et al. (2001) in a farmer's field experiment under moderate acidic soil also reported that application of organic resources alone and combined with inorganic resources recorded $5.81 \%$ and $5.83 \% \mathrm{~N}$ content, respectively, in the soybean Son et al. (2001) in a farmer's field experiment under moderate acidic soil also reported that application of organic resources alone and combined with inorganic resources recorded $5.81 \%$ and $5.83 \% \mathrm{~N}$ content, respectively, in the soybean grain. In addition, Tagoe et al (2008) found increased $10.1 \%$ and $40.6 \%$ in seed and plant total $\mathrm{N}$ content as affected by application of compost respectively. Application of lime increased soil $\mathrm{pH}$ and favored nitrogen fixation where $\mathrm{N}$ concentration in the plant was increased significantly by $3.1 \%$ as reported by Caires et al. (2006). Integrated application of lime and organic fertilizer increases the quality of soils, by reducing acidity and improving soil chemical and physical properties, serves as a source of nutrients, maintains soil moisture, neutralizes toxic $\mathrm{Al}$, increase availability of $\mathrm{P}$, reduce $\mathrm{P}$ fixation by $\mathrm{Al}$ and iron (Fe) oxides in the soil. Crawford et al. [33] Kisinyo et al. 2012). Anetor and Akinrinde (2006) reported 65.6\% increase in $P$ uptake by early growing soybean variety with application of lime (2-ton ha-1). In India application of combined compost (4.5-ton ha${ }^{1}$ ) increased soybean P uptake more than application of either sole compost (Toor, 2009). This was attributed to increased availability of $\mathrm{P}$ in the soil, enlarged proliferation of roots and to reduction of $\mathrm{Fe}$ and $\mathrm{Al}$ activity in the soil.

The combined application of lime and compost can also increase nodule weight of common bean. Bekere et al. [54] also observed $50 \%$ increases in nodule weight when common bean inoculated with and plant with compost and receiving lime Bekere et al. [54].The highest nodule weight under greater compost, liming and inoculation combination could be due to the fact that liming neutralizes the toxicity effects of $\mathrm{H}^{+}, \mathrm{Al}^{3+}$ and $\mathrm{Mn}^{4+}$ in the soil resulting suitable environment for survival of Rhizobium (Staley and Brauer [56]. Rhizobium inoculation and lime level had a significant effect on mean nodule number of haricot bean. At higher rate of liming and nodulation combination, nodule weight and nodule number increase due to the higher lime and Rhizobium inoculation.

\section{Effects of Compost and Lime on Soil Microbial Biomass}

The Soil Microbial Biomass (SMB) is the active component of the soil organic pool, playing an important role in nutrient cycling, plant nutrition, and functioning of different ecosystems. It is responsible for organic matter decomposition thus affecting soil nutrient content Onwonga et al. [25]. As such, the biomass is both a source and sink of the nutrients $\mathrm{C}, \mathrm{N}, \mathrm{P}$ and $\mathrm{S}$ contained in the organic matter (Lin et al., 2010; Basu et al., 2011). Soil microorganisms are significant determinants of organic matter decomposition, soil nutrient status, crop health, and overall crop productivity (Basu et al., 2011). Soil MB is undoubtedly a valuable tool for understanding and predicting changes in soil fertility management and associated soil conditions such as nutrient dynamics and soil reactions (Sharma et al., 2004). However, changes in soil conditions (plant or animal residues) will determine how fast the microbial biomass responds Onwonga et al. [25]. Therefore, the understanding of soil microbial biomass dynamics is the critical point in the management of acid soils.

Research suggests that repeated applications of organic amendments, such as animal manures, biosolids and composted materials can improve soil microbial biomass (SMB). Onwonga et al. [25] reported that manure significantly increased SMB throughout crop cycle. Similarly, Basu et al. (2011) found that the combined application of FYM with lime and chemical fertilizers increase Soil microbial biomass. Fuentes et al. (2006) reported that application of lime at the rate of 4.4-ton ha ${ }^{-1}$ increased soil microbial biomass by 3.3 times which was attributed to increased soil $\mathrm{pH}$.

\section{Effects of the Integration of Lime and compost on Above Ground Total Dry Biomass of common bean}

Lime applied to acid soils raises the $\mathrm{pH}$ of soils, resulting in enhanced availability of nutrients, such as $\mathrm{P}, \mathrm{Ca}, \mathrm{Mg}$, Mo and improved crop yields (Kisinyo et al., 2009; Fuentes et al. 2006). Additions of composts to acid soils can reduce all toxicity in soil and increase crop yields. Kimani et al. [57] reported a 92\% increase in yields after applying compost compared to the control. Combined application of compost + lime resulted in 147\% yield increase while application of FYM 5t/ha along with compost + lime further boosted the yield improvement up to $291 \%$ over control Manoj et al. [58].

Maintenance of the fertility status of the soil is an important aspect to obtain a stable and sustainable yield. The increase in the agronomic yield due to liming of acidic soils may be attributed to the reduction in acidity $(\mathrm{H}$ and $\mathrm{Al})$ ions and reduction in nutrient deficiency of Ca and P Curtin and Syers [51]. A study by Oluwatoyinbo et al. [59] also indicated the possibility of increasing the crop yield by improving soil acidity through the application of lime, and compost. According to this author the increase in crop yield through the application of lime may be attributed to the neutralization of $\mathrm{Al}$, supply of $\mathrm{Ca}$ and increasing availability of some plant nutrients like $\mathrm{P}$.

\section{Conclusion and recommendations}

Common bean is one of the most important and major grain legumes which have been consumed worldwide including our country for its edible seeds, cash crops, and source of protein for farmers. It's also among the top-ranking pulses in terms of area coverage and highly preferred by Ethiopian farmers because of its fast maturing and cultivated in most of the agro-ecological zones of low and mid altitude areas of Ethiopia [60-63]. However, the national average is by far below the average yield reported at research sites. This may be attributed to a combination of several 
production constraints such as Soil acidity, poor soil fertility management and low nutrient availability associated with low $\mathrm{pH}$ of the soils are among the tops.

Soil acidity is one of the most important soil factors which affect plant growth and ultimately limit common bean production. In acidic soils, the high content of $\mathrm{Al}$ and Fe oxides and hydroxides are the main factors accounting for the strong macronutrient consequently, limits crop production. Soil acidity has also been shown to be an important factor for Nutrient deficiency problem limiting legume production and reduces growth, nodulation, and $\mathrm{N} 2$ fixation. It's also toxic to plant roots and inhibit microorganism's activity, such as Rhizobium spp. To overcome these production constraints, the combined application of compost and lime are recommended to overcome the problem of soil acidity by raising acidic soil PH and to increase soil fertility.

\section{Prospects}

Although the effects of lime and compost application on common bean has been researched extensively, various aspects remain that need to be investigated. Major gaps in our knowledge of the combined impact of lime and compost application still exist $[64,65]$. Thus, future research endeavor should focus on:

a. The impact of combined lime and compost application based on their properties.

b. The use of additional Biochar and other soil amendment methods should be paramount in any future study to confirm the yield increment of common bean under acidic soil.

c. Knowledge is also lacking about the application and preparation of compost and lime needed for amendment.

\section{References}

1. (2013) FASOSTAT Food and Agricultural Organization of the United Nations, Italy.

2. (2015) FAOSTAT Food and Agricultural Organization of the United Nations, Italy.

3. Katungi N, Kasturikrishna S, IPS Ahlawat (2009) Growth and yield response of pea (Pisumsativum) to moisture stress, phosphorus, sulphur and zinc fertilizers. Indian Journal of Agronomy 44(3): 588-596.

4. Maiti RK, Singh VP (2007) Advances in Common Bean and Related Species, Agrobios (International). Plant Physiol 84: 835-840.

5. Brucher H, Trop, Nutzpfl, Springer V, Wolf G (1977) Distribution, Yield and Use of Common Beans/common bean.ntml). Via internet accessed.

6. Asfaw A, Blair MW (2014) Quantification of drought tolerance in Ethiopian common bean varieties. Agricultural Sciences 5(2): 124-136.

7. (2016) FAOSTAT.

8. Tumsa K, Buruchara R, Beebe SE (2014) Common Bean Strategies and Seed Roadmaps for Ethiopia. In: Monyo ES, Laxmipathi GCL (Eds.), Grain Legumes Strategies and Seed Roadmaps for Selected Countries in Sub Saharan Africa and South Asia, TL-II Project Report, ICRISAT, India, pp: 3-11.

9. Negash R (2007) Determinants of adoption of improved haricot bean production package in Alaba special woreda, southern Ethiopia, Doctoral dissertation, Haramaya University, Ethiopia.

10. (2010) FAOSTAT. Food and Agriculture Organization at www.fao.org.
11. Legesse DG, Kumssa T, Assefa M, Taha J, Gobena T, et al. (2006) Production and Marketing of White Pea Beans in the Rift Valley, Ethiopia. A Subsector Analysis. National Bean Research Program of the Ethiopian Institute of Agricultural Research.

12. (2015) CSA (Central Statistics Agency) Agricultural sample survey. Report on Land Utilization, Statistical Bulletin 278. Addis Ababa, Ethiopia.

13. Wortmann CS, Kirkby RA, Eledu CA, Allen DJ (1998) Atlas of common bean (Phaseolus vulgaris L.). Production in Africa. CIAT, Colombia, California, USA.

14. (2013) Central Statistical Agency (CSA) of Ethiopia. Agricultural Sample Survey, Addis Ababa, Ethiopia.

15. IFPRI (International Food Policy Research Institute) Pulses value chain potential in Ethiopia (2010) constraints and opportunities for enhancing exports. Pulses diagnostics.

16. Blair MW, Galeano CH, Tovar E, Muñoz Torres MC (2012) Castrillón Development of a Mesoamerican intra-genepool genetic map for quantitative trait detection in a drought tolerant $\times$ susceptible common bean (Phaseolus vulgaris L.) cross Molecular Breeding 29: 71-88.

17. Frehiwot M (2010) Profile of Haricot bean production, supply, demand and marketing issues in Ethiopia. Ethiopia Commodity Exchange Authority, Addis Ababa, Ethiopia.

18. Fageria NK (2002) Soil quality vs. environmentally based agricultural management practices. Communications in Soil Science and Plant Analysis 33: 2301-2329.

19. Asmare Abebe (2014) Haricot bean (Phaseolus vulgaris L.) varieties performance and recommended method of production. In: proceedings of the $19^{\text {th }}$ National Crop Improvement Conference, 22-26 April, IAR, Addis Ababa, Ethiopia.

20. Ponette Q, Belkacem S, Nys C (1996) Ion dynamics in acid forest soils as affected by addition of Ca fertilizers. Geoderma 71: 53-76.

21. Ndakidemi PA, Dakora FD, Nkonya EM, Ringo D, Mansoor H (2006) Yield and economic benefits of common bean (Phaseolus vulgaris) and soybean (Glycine max) inoculation in northern Tanzania. Animal Production Science 46: 571-577.

22. Slattery WJ, Coventry DR (1993) Response of wheat, triticale, barley, and canola to lime on four soil types in north-eastern Victoria. Australian Journal of Experimental Agriculture 33(5): 609-618.

23. Haynes RJ, Ludeke TE (1981) Effect of lime and phosphorus application on concentration of available nutrients and on $\mathrm{P}, \mathrm{Al}$ and $\mathrm{Mn}$ uptake by two pastures legumes in an acid soil. Plant and Soil 62(1): 117-128.

24. Mora ML, Demanet R, Vistoso E, Gallardo F (2005) Influence of sulphate concentration in mineral solution on ryegrass grown at different $\mathrm{pH}$ and aluminum levels. Journal of Plant Nutrition 28(7): 1117-1132.

25. Onwonga RN, Lelei JJ, Mochoge BB (2010) Mineral nitrogen and microbial biomass dynamics under different acid soil management practices for maize production. Journal of Agricultural Science 2(1): 1-30.

26. Broughton WJ, Hernández G, Blair M, Beebe S, Gepts P, et al. (2003) Beans (Phaseolus spp.) model food legumes. Plant and Soil, 252(1): 55-128.

27. Mamidi S, Rossi M, Moghaddam SM, Annam D, Lee R, et al. (2013) Demographic factors shaped diversity in the two gene pools of wild common bean Phaseolus vulgaris L. Heredity 110(3): 267-276.

28. Wortman CW, Ogawa M, Allen DJ (1998) African bean production environments: their detention, characteristics, and constraints. In: Net work on bean research in Africa. Occasional paper series number 11, Dare salaam, CIAT, Tanzania, p: 47.

29. Pachio D (1993) The demand for bean technology. In: Henery G (Ed.), Trends in CIAT Commodities. CIAT Working Document, 128: 60-73.

30. Addis Ababa (2000) CSA (Central Statistical Agency). Area and production of major crops. Ethiopia.

31. (1989a) CIAT (Centro International de Agricultural Tropical). Morphology of the common bean plant: Study guide to be used as a supplement to the audio-tutorial unit on the same topic. Colombia, California, USA 
32. Taye B (2008) Estimation of Lime Requirement. Training Manual for Regional Soil Testing Laboratory Heads and Technicians. National soil Testing Center, MOARD, India.

33. Crawford Jr TW, Singh U, Breman H (2008) Solving agricultural problems related to soil acidity in central Africa's great lakes region. CATALIST Project Report. International Center for Soil Fertility and Agricultural Development (IFDC), Kigali, Rwanda, pp: 1-133.

34. Kanyanjua SM, Ireri L, Wambua Stephen, Nandwa SM (2002) Acidic soils in Kenya: Constraints and remedial options. School of Agriculture and Veterinary Sciences.

35. He Z, Yang X, Baligar VC, Calvert DV (2003) Microbiological and biochemical indexing systems for assessing quality of acid soils. Advances in Agronomy 78: 89-138.

36. Brady NC, Weil RR (1999) The nature and properties of soil. $12^{\text {th }}$ (edn.).

37. Huber C, Baier R, Göttlein A, Weis W (2006) Changes in soil, seepage water and needle chemistry between 1984 and 2004 after liming an $\mathrm{N}$-saturated Norway spruce stand at the Höglwald, Germany. Forest Ecology and Management 233(1): 11-20.

38. Magdoff F (2001) Concept, components and strategies of soil health in agroecosystems. J Nematol 33(4): 169-172.

39. Forge TA, Hogue EJ, Neilsen G, Neilsen D (2008) Organic mulches alter nematode communities, root growth and fluxes of phosphorus in the root zone of apple. Applied Soil Ecology 39(1): 15-22.

40. Nilsson LO, Baath E, Falkengren Grerup U, Wallander H (2007) Growth of ectomycorrhizal mycelia and composition of soil microbial communities in oak forest soils along a nitrogen deposition gradient. Oecologia 153(2): 375-384.

41. Lauber CL, Hamady M, Knight R, Fierer N (2009) Pyrosequencing based assessment of soil $\mathrm{pH}$ as a predictor of soil bacterial community composition at the continental scale. Appl Environ Microbiol 75(15): 5111-5120.

42. Jenkins SN, Waite IS, Blackburn A, Husband R, Rushton SP, et al. (2009) Actinobacterial community dynamics in long term managed grasslands. Antonie Van Leeuwenhoek 95(4): 319-334.

43. Sharif M, Matiullah K, Tanvir B, Shah AH, Wahid F (2011) Response of fed dung composted with rock phosphate on yield and phosphorus and nitrogen uptake of maize crop. African Journal of Biotechnology 10(59): 12595-12601.

44. Kucey RM (1989) Increased P uptake by wheat \& soybean application with Rock Phosphate inoculated with P solubilizing microorganisms. Environmental Microbiology 52: 2699-2703.

45. Ristow PL, Foster J, Ketterings QM (2010) Lime guidelines for field crops; tutorial workbook. Department of animal science. Cornell University, Ithaca, p: 47.

46. Souza RFD, Faquin V, Lima Sobrinho RR, Oliveira EABD (2010) Influence of cattle manure and limestone on residual effects of phosphorus fertilizer in Brachiaria brizantha grown after common bean. Rev Bras Ciênc Solo 34(1): 143-150.

47. Asgelil D (2000) Effect of fertilizer on the yield and nodulation pattern of faba bean on a Nitisols of Adet, Northwestern Ethiopia. Ethiopian Journal of Natural Resource 2: 237-244.

48. Getachew A, Taye B, Agajie T (2005) Phosphorus fertilizer and farmyard manure effects on the growth and yield of faba bean and some soil chemical properties in acid Nitisols of the central highlands of Ethiopia. Ethiopian Society of Soil Science 7: 23-39.

49. Manisha B, Singh PBB, Mahapatra SC (2007) Comparative effectiveness of different organic and industrial wastes on peanut: plant growth, yield, oil content, protein content, mineral composition and hydration coefficient of kernels. Archives of Agronomy and Soil Science 53(6): 645658.

50. Fekadu E, Kibret K, Melese A, Bedadi B (2018) Yield of faba bean (Vicia faba L.) as affected by lime, mineral P, farmyard manure, compost and rhizobium in acid soil of lay Gayint District, northwestern highlands of Ethiopia. Agriculture \& Food Security 7(1): 1-16.

51. Curtin D, Smillie GW (1995) Effects of incubation and pH on soil solution and exchangeable cation ratios. Soil Science Society of America Journal 59(4): 1006-1011.

52. Suarez DL, Simunek J (1997) UNSATCHEM: Unsaturated water and solute transport model with equilibrium and kinetic chemistry. Soil Sci Soc Am J 61(6): 1633-1646.

53. Lucrecia M, Ramos G, Boddey RM (1987) Yield and nodulation of Phaseolus vulgaris and the competitivity of an introduced Rhizobium strain: effects of lime, mulch and repeated cropping. Soil Biology and Biochemistry 19(2): 171-177.

54. Bekere W, Kebede T, Dawud J (2013) Growth and nodulation response of soybean (Glycine max L.) to lime, Bradyrhizobium japonicum and nitrogen fertilizer in acid soil at Melko, South western Ethiopia. International journal of Soil Science 8(1): 25-31.

55. Hartley E, Greg Gemell L, Herridge FD (2004) Lime pelleting inoculation serradella (Ornithopus spp.) increases nodulation and yield. Soil Biology and Biochemistry 36(8): 1289-1294.

56. Staley TE, Brauer DK (2006) Survival of a genetically modified rootcolonizing pseudomonad and rhizobium strain in an acidic soil. Soil Sci Soc Am J 70(6): 1906-1913.

57. Kimani SK, JM Macharia, C Gachengo, CA Palm, RJ Delve (2004) Maize production in the central highlands of Kenya using cattle manures combined with modest amounts of mineral fertilizer. Uganda Journal of Agricultural Sciences 9: 480-490.

58. Manoj Kumar, S Hazarika, BU Choudhury, BC Verma, LJ Bordoloi (2012) Liming and Integrated Nutrient Management for Enhancing Maize Productivity on Acidic Soils of Northeast India. Indian Journal of Hill Farming 25(1): 35-37.

59. Oluwatoyinbo FI, Akande MO, Adediran JA (2005) Response of okra (Abelmoschus esculentus) to lime and phosphorus fertilization in an acid soil. World Journal of Agricultural Sciences 1(2): 178-183.

60. Bambara S, Ndakidemi PA (2010) Changes in selected soil chemical properties in the rhizosphere of Phaseolus vulgaris $L$. supplied with Rhizobium inoculants, molybdenum and lime. Scientific Research and Essays 5(7): 679-684.

61. Branca G, Lipper L, McCarthy N, Jolejole MC (2013) Food security, climate change, and sustainable land management. A review. Agronomy for Sustainable Development 33(4): 635-650.

62. Karhu K, Mattila T, Bergström I, Regina K (2011) Biochar addition to agricultural soil increased $\mathrm{CH}_{4}$ uptake and water holding capacityResults from a short-term pilot field study. Agriculture, Ecosystems \& Environment 140(1-2): 309-313.

63. Manivannan S, Balamurugan M, Parthasarathi K, Gunasekaran G, Ranganathan LS (2009) Journal of Environmental Biology 30: 275-281.

64. Sanchez PA, W Couto, SW Boul (1982) The fertility capability soil classification system: interpretation, applicability and modification. Geoderma 27(4): 283-309.

65. Ambawade MS, Pathade GR (2015) Production of indole acetic acid (IAA) by Stenotrophomonas maltophilia BE25 isolated from roots of banana (Musa spp). International Journal of Science and Research 4: 2644-2650. 